\title{
5. The Sex Discrimination Act at 25: Reflections on the Past, Present and Future
}

\author{
Beth Gaze
}

The Sex Discrimination Act (SDA) was adopted against strident opposition in 1984. This chapter critically analyses its effect after 25 years. The symbolic impact of prohibiting sex discrimination is highly significant, but the real impact of the Act on practices in the workforce and elsewhere appears more limited. Although formal exclusion of women has largely passed, informal practices of discrimination continue. Not only is Australia far from reaching substantive equality for women, it has moved backwards in recent years. This chapter considers what the SDA could achieve and its limits, and whether reforming the Act would move us closer to its avowed objectives of 'eliminating discrimination against persons on the ground of sex' and 'promot[ing] recognition and acceptance within the community of the principle of the equality of men and women'.

\section{Introduction}

The Commonwealth Sex Discrimination Act 1984 (SDA) turned 25 in August 2009. Has it come of age as a full-grown and effective piece of legislative regulation? Or is it instead a case of arrested development? Answering this question requires an evaluation of the effects of the SDA against a background of extensive social change over 25 years and persistent sex differentiation in our society. Analysing changes in large-scale social phenomena such as gender relations or workplace practices is challenging, and identifying operative causes of change from among the multitude of factors that affects these social institutions is even more difficult. Conclusive and comprehensive answers about the effects of such legislation are elusive. Hunter has argued that the SDA has been overtaken by social and political change, which has rendered it relatively ineffective to change things for women. ${ }^{1}$ Thornton has noted that the courts have tended to interpret the Act to preserve current arrangements, rather than to bring about change. ${ }^{2}$

\footnotetext{
1 Rosemary Hunter, 'The Mirage of Justice: Women and the Shrinking State' (2002) 16 Australian Feminist Law Journal 53.

2 Margaret Thornton, 'Auditing the Sex Discrimination Act' in Marius Smith (ed.), Human Rights 2004: The Year in Review, Castan Centre for Human Rights Law, Monash University, Melbourne, 2005, p. 21.
} 
This chapter assesses the Act's influence and argues that despite its undeniable achievements, there is cause for concern about its current and future roles, and that more than cosmetic reform is necessary. Since the Act was adopted, a generation of women has grown to maturity with its promise of equality. Over the decades, however, experience with the Act has shown that its response to sex discrimination is severely limited in vital respects and the promise of equality has not been fulfilled.

\section{The Sex Discrimination Act}

There is no doubt that the $S D A$ was a vital legislative milestone in Australia. It was a national proclamation that sex discrimination was unacceptable throughout the country. This was a crowning achievement of the efforts of second-wave feminist activists. Although Victoria and New South Wales had legislated in 1977 to prohibit sex discrimination, and Western Australia and South Australia did so in 1984, the SDA first prohibited sex discrimination in the other States and Territories and federal activities. ${ }^{3}$ It clearly precluded overt formal distinctions based on sex. Jobs could no longer be advertised for 'men and boys' or 'women and girls', with the better jobs in the former category. ${ }^{4}$ Women could no longer be paid two-thirds of men's rates for the same work, ${ }^{5}$ excluded from jobs or from promotion simply because they were female or dismissed from their jobs simply because they married or became pregnant. Compared with what preceded it, the Act's practical and symbolic effects were enormously significant and produced major advances in women's positions. From today's perspective, however, where formal equality has been established for three decades, it is easier to see the Act's limitations, its disappointing record in the courts and the need for further changes.

One of the most important achievements of the Act was the creation of the office of the Sex Discrimination Commissioner, which has been occupied by a series of courageous, articulate women (including the current Governor-General, Quentin

\footnotetext{
3 Anti-Discrimination Act 1977 (NSW), Equal Opportunity Act 1977 (Vic.), Equal Opportunity Act 1984 (SA), Equal Opportunity Act 1984 (WA). South Australia was the first state to legislate to prohibit discrimination in Australia, but its first legislation was directed only to racial discrimination; the Prohibition of Discrimination Act 1966 (SA), which contained only criminal penalties, was replaced by the Racial Discrimination Act 1976 (SA).

4 Susan Magarey, this volume.

5 In Australia, equal pay has traditionally been dealt with in industrial rather than equal opportunity law. Equal pay principles adopted in industrial cases in 1969 (equal pay for equal work) and 1972 (equal pay for work of equal value) were limited in scope, and further effort was required for implementation in specific areas of the labour market. Many women worked in female-dominated industries in which all employees received low pay, so women's wages remained inequitably lower than men's. Attempts to run cases on the value of women's jobs, such as nursing, were unsuccessful: Jane Innes, 'Claiming Equal Pay for Work of Equal Value: The ACTU's Comparable Worth Test Case' (1986) 4 Law Society Journal 52; Jane Innes, 'Equal Pay and the Sex Discrimination Act 1984' (1986) 11 Legal Service Bulletin 254.
} 
Bryce), who have been prepared to enter sometimes hostile public debate to raise issues that need attention and to press for reform. They have kept issues of importance to women on the agenda, including sexual harassment, pregnancy discrimination, work and family conflict and the need for paid maternity leave. ${ }^{6}$ Most have not yet received adequate social or legislative responses.

The SDA prohibits discrimination on the basis of sex, marital status, pregnancy and sexual harassment (not merely discrimination against women) ${ }^{7}$ with potential pregnancy, breastfeeding and limited family responsibilities grounds added later. Such discrimination is prohibited in the areas of employment (including selection), education, provision of goods and services, accommodation, clubs and government administration. Two main types of discrimination are prohibited. ${ }^{8}$ Direct discrimination occurs where a person is treated less favourably on the ground of sex, marital status, pregnancy or potential pregnancy than a person of a different sex in circumstances that are not materially different. Indirect discrimination occurs where a group of people of a particular sex or marital status is disadvantaged by the effect of an apparently neutral condition, requirement or practice, where that practice is not reasonable. The Act is enforced solely by private litigation. Although it contains provision for some criminal offencesfor example, for advertising that indicates an intention to discriminate ${ }^{9}$ or for victimisation $^{10}$ - there are no reported cases in which these provisions have been enforced.

\section{Direct Discrimination and Formal Equality}

The initial impact of direct sex discrimination law was illustrated by the 1980 decision in Ansett Transport Industries $v$ Wardley, ${ }^{11}$ in which the High Court

6 See Human Rights and Equal Opportunity Commission, The Equal Pay Handbook,1998; Pregnant and Productive: It's a Right not a Privilege to Work while Pregnant, 1999; A Bad Business: Review of Sexual Harassment in Employment Complaints, 2002; A Time to Value: Proposal for a National Scheme of Paid Maternity Leave, 2002; Striking the Balance: Women, Men, Work and Family, 2005; Sexual Harassment: Serious Business, 2008.

7 Unlike the International Convention on the Elimination of All Forms of Discrimination Against Women (CEDAW) (opened for signature on 1 March 1980, 1249 UNTS 13, entered into force on 3 September 1981), which is asymmetrical, aimed only at discrimination against women, the SDA can rely on Australia's obligations in relation to sex discrimination in international law only in relation to discrimination against women, and the constitutional basis of its prohibition on sex discrimination against men is unclear. See also the Australian Law Reform Commission (Equality Before the Law: Justice For Women, Report No. 69, Australian Law Reform Commission, Sydney, 1994), in which the majority recommendation was for an Equality Act with a symmetrical equality provision, while a minority of commissioners preferred legislation directed to equality for women.

8 SDA, ss 5-7C.

9 SDA, s. 86.

10 SDA, s. 94.

11 Ansett Transport Industries (Operations) Pty Ltd $v$ Wardley ((1980) 142 CLR 237; [1980] HCA 8) was brought under the equivalent direct discrimination provisions of the Victorian Equal Opportunity Act 1977. 
upheld the law's prohibition on excluding a woman from recruitment as a trainee pilot simply because she was female. After this decision, it was clear that refusing to employ a woman on the ground of sex was unlawful. Formal equality appeared to have been achieved, at least where the refusal was overtly based on sex. The decision is, however, an excellent example of the difference between a legal victory and a broad social change: nearly 30 years after Wardley's case, most of us will rarely have been on a commercial airline flight with a female pilot in charge. The absence of women pilots and captains provides the clearest evidence of the state of practical equality of opportunity in Australia now. The absence of women is reflected in innumerable positions of power and influence throughout our society despite decades of sex discrimination law. Simply removing the most formal of exclusionary practices did not dissolve barriers.

Traditional attitudes, practices and social patterns did not disappear, but found other avenues of expression. The social structures of gender, race, sexuality and ability all continued (and still continue) to affect opportunities and expectations, while the target became less overt and hence more difficult to identify. Discrimination turned out to be a stronger and more subtle phenomenon than the law had anticipated and the law a correspondingly weaker tool against it. In particular, dealing with areas of women's difference from men, such as pregnancy and the need for maternity leave, through an area of law that insists on comparative assessment leads to incoherence. Pregnancy is not merely comparable with extended sick leave for an illness, although the cases on pregnancy discrimination treat it this way in order to find a comparator for assessing whether treatment was less favourable. ${ }^{12}$ Such a comparison is highly artificial and deprives any analysis of an adequate consideration of the contextual issues that surround discrimination based on pregnancy and having taken maternity leave. It evidences the law's inability to see women's lives except through the prism of men's experience. ${ }^{13}$

The courts have not seen sex discrimination laws as requiring them to pursue the social goal of equality or equity beyond the minimal level. They have insisted that the person complaining of direct discrimination has to prove that the prohibited ground was the basis of the action against her, even though

\footnotetext{
Ansett refused to recruit Deborah Wardley as a pilot even though her scores on intake testing were higher than those of some men who were recruited, because Mr Ansett did not want women flying his planesasserting that passengers would not feel safe.

12 See, for example: Howe $v$ Qantas Airways Ltd (2004) 188 FLR 1; [2004] FMCA 242; Iliff v Sterling Commerce (Australia) Pty Ltd [2007] FMCA 1960; Fenton v Hair \& Beauty Gallery Pty Ltd \& Anor [2006] FMCA 3. A woman who is ill during pregnancy would be entitled to sick leave, but pregnancy involves normal incidents that cannot necessarily be analogised to sickness - for example, the need for time off for regular medical checks of normal progress.

13 See, for example: Catharine MacKinnon, Feminism Unmodified: Discourses on Life and Law, Harvard University Press, Cambridge, Mass., 1987; Regina Graycar and Jenny Morgan, The Hidden Gender of Law, Second edition, Federation Press, Sydney, 2002.
} 
knowledge and evidence of the actual basis of the decision or action are in most cases confined to the respondent. ${ }^{14}$ The courts have also been influenced by two other social factors that operate as major barriers to women's equality at work: managerial prerogative (where courts can be reluctant to constrain too far the freedom of an employer to make choices) and the 'market' defence (where a respondent argues that they are acting only to provide what the market - that is, the customer - demands). Judges are often reluctant to infer that a respondent acted on a prohibited basis, unless there is clear evidence of that basis - for example, in admissions by the respondent. ${ }^{15}$ In defence, respondents often argue that the complainant was not competent or had personality problems that contributed to the events in dispute. The personal strain of running a case in which such allegations will be raised is obvious and, along with the financial costs of running a case and the risks of ending up with an order to pay the other side's costs, is a major disincentive to bringing a claim. ${ }^{16}$

During the 2000s, there was discussion about the need for a more effective method of proof of direct discrimination, such as exists in many other comparable countries. ${ }^{17}$ In Europe and the United Kingdom, for example, once a prima facie case is established, the onus of proof shifts to the respondent to show that it was not based on the prohibited ground. ${ }^{18}$ Legislative reforms to this effect have been recommended by government inquiries, ${ }^{19}$ but no such reform has yet occurred.

\section{The SDA in the Courts}

In this section, the experience of litigation under the $S D A$ is reviewed from two perspectives. First, the reported cases on the $S D A$ in the past 10 years are analysed to see what this indicates about the state of usage of the law. Then legal doctrine from some high-profile decisions is analysed. Strangely enough given the $S D A$ 's symbolic importance, the High Court has never decided a case on its substantive provisions. ${ }^{20}$ All the sex discrimination cases that have

\footnotetext{
14 See Neil Rees, Katherine Lindsay and Simon Rice, Australian Anti-Discrimination Law: Text, Cases and Materials, Federation Press, Sydney, 2008, pp. 146-55; Jonathon Hunyor, 'Skin-Deep: Proof and Inferences of Racial Discrimination in Employment' (2003) 25 Sydney Law Review 535; Dominique Allen, 'Reducing the Burden of Proving Discrimination in Australia' (2009) 31 Sydney Law Review 579.

15 Thomson v Orica Australia Pty Ltd (2002) 116 IR 186; [2002] FCA 939.

16 Beth Gaze and Rosemary Hunter, Enforcing Human Rights In Australia: An Evaluation of the New Regime, Federation Press, Sydney, (forthcoming).

17 Hunyor, 'Skin-Deep', and Allen, 'Reducing the Burden of Proving Discrimination in Australia'.

18 This is required by a European Union Directive on the Burden of Proof, Council Directive 97/80/EC (see also 98/52/EC), discussed in Rees et al., Australian Anti-Discrimination Law, p. 150.

19 Department of Justice, An Equality Act for a Fairer Victoria, Final Report, Equal Opportunity Review, Department of Justice, Government of Victoria, Melbourne, 2008, <http://www.justice.vic.gov.au/wps/wcm/ connect/DOJ+Internet/Home/Your+Rights/Equal+Opportunity/>

20 The reasons for the absence of High Court decisions on the SDA are not clear. In contrast, there have been several High Court decisions on the Disability Discrimination Act 1992 (Cth) (DDA) and the Racial
} 
gone to the High Court have been appeals under State sex discrimination law: Wardley from Victoria, and from New South Wales, Dao v Australia Post, AIS $v$ Banovic and NSW $v$ Amery. ${ }^{21}$ Only Re McBain involved the SDA itself. ${ }^{22}$ In that case, the Federal Court had held that the Infertility Treatment Act 1995 (Vic.) was inconsistent with the SDA and invalid to the extent of the inconsistency under Section 109 of the Constitution. On appeal, the High Court did not consider the $S D A$, but decided the case on grounds relating to the prerogative remedy of certiorari. ${ }^{23}$ The cases decided on equivalent provisions in State sex discrimination laws are, however, applicable to the $S D A$, so this analysis draws on those cases and lower federal court decisions on the $S D A$.

The litigation record under the $S D A$ in the lower federal courts is equivocal. Before 2000, claims under the SDA were heard in the Human Rights and Equal Opportunity Commission, which acted as a tribunal. Constitutional problems, however, led to the recasting of the enforcement system. ${ }^{24}$ In 2000 , enforcement of cases under the $S D A$ that did not settle at conciliation was moved from a tribunal to the Federal Magistrate's Court (FMC) and the Federal Court. Less complex cases are heard in the FMC, while cases expected to run for more than two days may be heard in the Federal Court. In both courts, the losing party is usually ordered to pay the winner's costs, but in the FMC the costs scale, and therefore the risks of litigation are lower than in the Federal Court.

From 2000 to 2009, the Federal Magistrate's Court heard 46 substantive sex discrimination matters - an average of five cases each year. Of these, 12 were unsuccessful while 34 were successful. Almost all of the successful sex discrimination claims related to employment and more than half (20) involved sexual harassment claims. The damages awards have ranged from $\$ 750$ to $\$ 100$ 000 , but in only four cases was more than $\$ 25000$ compensation awarded, with the highest award being $\$ 100000$ awarded to a female civilian employee at a naval base who was sexually harassed, including rape. ${ }^{25}$ The median damages award in the FMC was $\$ 12000$, and several cases had damages awarded in the range $\$ 1-2000$. Although damages assessment is intended to be compensatory, little is given by way of general damages, which suggests that the courts regard the harms women suffer from discrimination and sexual harassment as not very serious. Since the enforcement of the Act rests on private litigation, damages awards of less than $\$ 2000$ after undertaking the personal and financial risks

\footnotetext{
Discrimination Act 1975 (Cth) (RDA).

21 Ansett Transport Industries (Operations) Pty Ltd $v$ Wardley (1980) 142 CLR 237; [1980] HCA 8; Dao v Australian Postal Commission (1987) 162 CLR 317 [1987] HCA 13; Australian Iron \& Steel Pty Ltd v Banovic (1989) 168 CLR 165; [1989] HCA 56 ('Banovic'); New South Wales v Amery (2006) 230 CLR 174; [2006] HCA 14.

22 Re McBain; Ex parte Australian Catholic Bishops Conference (2002) 209 CLR 372; [2002] HCA 16.

23 Kristen Walker, 'The Bishops, the Doctor, his Patient and the Attorney-General: The Conclusion of the McBain Litigation' (2002) 30 Federal Law Review 507.

24 Brandy v Human Rights \& Equal Opportunity Commission (1995) 183 CLR 245; [1995] HCA 10.

25 Lee $v$ Smith \& Ors [2007] FMCA 59.
} 
inherent in litigation suggest that there is a serious problem with incentives for enforcement, especially as legal aid for $S D A$ matters is very difficult to obtain. ${ }^{26}$ When sexual harassment cases are taken out of these data, the FMC upheld 14 claims over 10 years of discrimination based on sex, pregnancy or family responsibilities. Only two of these cases involved a successful indirect discrimination claim.

Since 2000, the Federal Court has heard 14 substantive matters under the $S D A$ and upheld five of them (about 36 per cent) - four of which were sexual harassment matters. In one sexual harassment case, the respondent did not appear and damages of $\$ 10000$ were awarded. ${ }^{27}$ In the other sexual harassment cases, damages awards were $\$ 20000,{ }^{28} \$ 24000^{29}$ and, in the most recent case, $\$ 466$ 000, where a relatively well-paid real estate agent lost her job and was unable to work for some time. ${ }^{30}$ The last case is, however, under appeal to the Full Federal Court at the time of writing. The other awards not only reflect a low valuation of the harms that women suffer in discrimination, they are outweighed by the risk of paying very substantial costs to the other party as well as one's own costs if Federal Court litigation is lost, leaving very little incentive to enforce the law. There was only one successful case of sex discrimination in the Federal Court in the period 2000-09, in which no damages award was made, as the outcome was negotiated between the parties after the finding of liability had been made. ${ }^{31}$

Since 2000, there have been 13 appeals in SDA matters in the Federal Court, mainly against FMC decisions. Of eight appeals brought by complainants, two have succeeded, and of five brought by respondents against a finding of liability, two were successful. In one of those appeals, the matter was remitted to the FMC for rehearing, where the sexual harassment claim was upheld again. ${ }^{32}$ In the other appeal, the Federal Court decided that an indirect discrimination claim must fail, but upheld a family responsibilities discrimination claim. ${ }^{33}$

This analysis shows that in the Federal Court, only one case of (direct) sex discrimination (rather than sexual harassment) has been upheld in a contested hearing since 2000, and that was a case in which there were statements by the complainant's supervisor deploring her falling pregnant. ${ }^{34}$ In the FMC, there

\footnotetext{
26 Beth Gaze and Rosemary Hunter, 'Access to Justice for Discrimination Complainants: Courts and Legal Representation' (2009) 32 University of New South Wales Law Journal 699.

27 Grulke v K C Canvas Pty Ltd [2000] FCA 1415 - although the judgment does not outline the nature of the discrimination involved.

28 Elliott $v$ Nanda \& Commonwealth (2001) 111 FCR 240; [2001] FCA 418.

29 Gilroy $v$ Angelov [2000] FCA 1775.

30 Poniatowska $v$ Hickinbotham [2009] FCA 680.

31 Thomson $v$ Orica.

32 Kirkland $v$ Wattle [2002] FCA 145; Wattle $v$ Kirkland \& Anor (No. 2) [2002] FMCA 135.

33 Commonwealth of Australia $v$ Evans (2004) 81 ALD 402; [2004] FCA 654.

34 Thomson $v$ Orica. The presence of direct evidence of the employer's hostility towards the employee's pregnancy was important to the finding that the employer's actions were based on pregnancy. Without this
} 
were 12 cases during this decade in which a claim of discrimination based on sex, pregnancy or family responsibilities was upheld. Only two cases involved a successful claim of indirect discrimination. For a national law on sex discrimination, which has stronger provisions in relation to indirect discrimination law than most State laws (as discussed below), there is a question as to why it has not had more use. Perhaps stronger cases might have been settled before hearing or brought in the State systems to avoid the risks of paying costs in Federal Court litigation, especially as damages awards were quite low. While larger amounts can be obtained in private or conciliated settlements, the lack of publicity and precedent means that such cases cannot serve the public interest by establishing precedents on either liability or quantum of damages that might assist the elimination of sex discrimination more broadly. Whatever the reason, these statistics raise serious concerns about the attractiveness of the $S D A$ as providing a remedy for discrimination. There is a need for some research to identify whether cases are being deterred or whether they are obtaining advantageous settlements by means other than litigation. We now turn to the doctrinal decisions of the courts on sex discrimination matters.

The largest category of successful claims under the SDA since 2000 has been sexual harassment, followed by termination based on family responsibilities and then pregnancy discrimination. ${ }^{35}$ In these categories, the issues of proof present less of a barrier. In sexual harassment cases, there is often a question of credibility if there were no witnesses to conduct that was alleged to have occurred, but if the complainant is found to be credible, there is no need to show the basis of the action or to identify a comparator. In family responsibilities matters, the discrimination is often directly linked to limits on the employee resulting from caring needs, so establishing the basis is less problematic. In pregnancy discrimination matters, courts have been more willing to infer pregnancy was a cause. ${ }^{36}$ The employment consequences of losing a job during pregnancy can be very serious. Because most 'good' jobs are advertised only as full-time, many women access them by returning part-time after childbirth to their own job. Pregnancy discrimination can deprive a woman of the chance to request flexible work in her existing job. It can be impossible to get another similar job part-time after the birth, so the employment setback can have very significant long-term consequences. Recent moves to provide a right to request

evidence, success would have depended on whether the court was prepared to infer such a motivation.

35 Of the successful cases, the grounds involved in the Federal Court were: sexual harassment in four out of five successful cases, pregnancy-related discrimination in the other. In the FMCA, sexual harassment was the basis in 21 of the 34 successful or partly successful matters, with family responsibilities discrimination in seven and pregnancy discrimination in four cases. There is some overlap in the grounds in the FMCA cases, as some cases involved more than one of these grounds.

36 It is difficult to determine the exact extent of particular discrimination in the workforce. See the discussion of this problem in Human Rights and Equal Opportunity Commission, 'Statistics and the extent of discrimination', Pregnant and Productive: It's a Right not a Privilege to Work while Pregnant, Human Rights and Equal Opportunity Commission, Sydney, 1999. 
flexible work could help, although some contain an inbuilt barrier by requiring a qualifying period of one year's (presumably inflexible) work before a request can be made. ${ }^{37}$ If they are used more by women than men, employers might try to minimise or avoid employment of women they think are likely to make use of this right.

\section{Indirect Discrimination and Equality}

Wardley confirmed that direct discrimination requires that women be treated the same as men, and the law takes this to be equality. ${ }^{38}$ Hence, once formal exclusion of women was prohibited, workforce practices moved from exclusion to treating women as if they were men. In a social and employment context designed by men for men, treating women as if they were men cannot provide genuine equality, as data on women's progress in a number of areas (discussed below) indicate. This approach is clearly contrary to the concept of equality in international conventions, which acknowledge that where women are situated differently they need different treatment. ${ }^{39}$ Refusing to take account of pregnancy and childbirth, ${ }^{40}$ and responsibilities for care of dependants such as children, people with disabilities and the elderly, reinforces the disadvantages experienced by the group that tends to be allocated these responsibilitiesdisproportionately women.

The persistence of discriminatory employment practices made it clear that sex discrimination law needed better tools to tackle covert and systemic practices, and indirect discrimination law appeared to have some promise. ${ }^{41}$ Indirect discrimination had significant potential to expand the idea of equality that is protected by sex discrimination law by allowing challenges to broad-based practices that have the effect of disadvantaging women. There is no need to show the 'true basis' for the respondent's action, although the claimant must establish that women (or pregnant women, and so on) are disadvantaged by the practice. $^{42}$

\footnotetext{
37 Fair Work Act 2009 (Cth), s. 65(2). In contrast, the duty not to refuse unreasonably a request for flexible work in the Equal Opportunity Act 1995 (Vic.) is not conditioned on a particular length of time in employment: see ss $13 \mathrm{~A}$ and $14 \mathrm{~A}$.

38 See Regina Graycar and Jenny Morgan, ‘Examining Understandings of Equality: One Step Forward, Two Steps Back?' (2004) 20 Australian Feminist Law Journal 23; Regina Graycar and Jenny Morgan, 'Thinking About Equality' (2004) 27 University of New South Wales Law Journal 833; Regina Graycar and Jenny Morgan, this volume.

39 See, for example, CEDAW, Article 4(1).

40 Although unpaid parental leave has been provided under industrial law and many employers have provided paid maternity leave voluntarily, there is no current entitlement to paid maternity leave. Government policy is to make a scheme available from 2011, but the legislation had not been passed at the time of writing.

41 Rosemary Hunter, Indirect Discrimination in the Workplace, Federation Press, Annandale, NSW, 1992.

42 SDA, ss 5(2), 6(2), 7(2), 7B and 7C.
} 
Some advances have been made though indirect discrimination law in challenging widely accepted and facially neutral workforce practices that were not necessarily imposed intentionally to harm women, even though this was their effect. Indirect discrimination was, however, developed from the American disparate impact principle adopted by the US Supreme Court in Griggs $v$ Duke Power Company ${ }^{43}$ to deal with a test imposed by an employer whose covert aim was to continue the racial segregation of its workforce. It has been contended that the aim of indirect discrimination was merely to prevent this type of covert direct discrimination - that is, neutral practices chosen to exclude particular groups. ${ }^{44}$ Indirect discrimination law was not really designed to deal with the much more subtle and widespread issues facing women at work, which are less obviously based in prejudice and tend to be more structural and based on widespread assumptions of naturally different gender roles and preferences. Australian anti-discrimination laws, including the $S D A$, contain no basis for limiting the scope of indirect discrimination only to situations of covert intentional discrimination, and instead appear to create an avenue to challenge any neutral social practice that has a differential impact on or disadvantages women.

The idea that the same treatment that disadvantages people with a particular attribute is discriminatory is potentially revolutionary because it offers the opportunity to challenge apparently neutral social and employment practices. Similar to the fate of direct discrimination law, however, barriers to litigation and court resistance to giving effect to the full implications of indirect discrimination mean its potential has never been realised. Practices that disadvantage are unlawful only if they are 'not reasonable' and, until 1995, the complainant had the onus of proving this negative and vague proposition, despite not having access to information on why the respondent might have imposed the requirement. The ambiguity of the limit perhaps reflects ambivalence and lack of clarity in what indirect discrimination is really intended to challenge.

The first case in the High Court, Banovic, ${ }^{45}$ received a sympathetic decision that upheld a finding of indirect discrimination in the retrenchment of women from a workforce under a last-on first-off policy, where they were last on because of prior biased and discriminatory recruiting. In Banovic, the SDA required the complainants to prove that the requirement affected a higher proportion of women than of men and that the practice involved was 'not reasonable'. The issue of proportionality was complex because the composition of the workforce was biased by the previous discrimination that had made it much

43401 US 424 (1971); (1971) 28 L Ed 2d 158.

44 R. Primus, 'Equal Protection and Disparate Impact: Round Three' (2003) 117 Harvard Law Review 493, cited by Rees et al., Australian Anti-Discrimination Law, pp. 120-2.

45 Banovic. 
harder for women to get jobs than for men. The decision centred on working out statistical ratios rather than assessing the discriminatory impact of the practice. This reflects a common approach in discrimination litigation in Australia of preoccupation with technicalities rather than the substantial issues presented. While some technical legal analysis might be unavoidable, it has often been allowed to dominate interpretation of the law at the expense of its purposes. ${ }^{46}$

In case law in the lower courts, the interpretation of 'not reasonable' has been contentious and unpredictable, leading to conservative and narrow interpretations of indirect discrimination provisions. Although a number of cases succeed in the Human Rights and Equal Opportunity Commission on indirect discrimination, judicial decisions reviewing them for error have been variable and unpredictable and have tended to overturn tribunal decisions, ${ }^{47}$ creating high levels of litigation risk and deterring litigation. In all three Full Federal Court judicial review (appeal) cases concerning the SDA decided under the pre-2000 enforcement system, the Court set aside decisions of the Human Rights and Equal Opportunity Commission in favour of a complainant on the basis that they had not established that the requirement was 'not reasonable'. ${ }^{48}$ No such case was decided in favour of a complainant. As already noted, this is a major problem in a system that relies solely on enforcement through individual litigation.

In the early 1990s, the SDA was reviewed by the House of Representatives Legal and Constitutional Committee, whose report, Half Way to Equal (1992), identified a number of changes to improve the effectiveness of the law. The Australian Law Reform Commission's review of Equality before the law followed in 1994, providing further ideas for strengthening the law. Some of these ideas were implemented in reforms to the Act in 1992 and 1995, which rendered it the most advanced anti-discrimination law in Australia. Of particular importance were changing the definition of indirect discrimination to focus on practices that disadvantage members of one sex, rather than technical assessments of disproportionate impact and inability to comply, and reversing the onus of proof of 'not reasonable' in indirect discrimination, so that the respondent had to prove that its requirement or practice was reasonable. ${ }^{49}$

\footnotetext{
46 Beth Gaze, 'Context and Interpretation in Anti-Discrimination Law' (2002) 26 Melbourne University Law Review 325.

47 For example, Sheppard J in Commonwealth v Human Rights and Equal Opportunity Commission (1995) 63 FCR 74 (Dopking No. 2) thought all the test required was 'whether a respondent's conduct was logical and understandable', whereas this was said to set too low a standard by Sackville J in Commonwealth Bank of Australia v Human Rights and Equal Opportunity Commission (1997) 80 FCR 78; 150 ALR 1. See Margaret Thornton, 'The Indirection of Sex Discrimination' (1993) 12 University of Tasmania Law Review 88.

48 Secretary, DFAT v Styles (1989) 23 FCR 251; 88 ALR 621; Commonwealth Bank of Australia $v$ Human Rights and Equal Opportunity Commission (1997) 80 FCR 78; 150 ALR 1; Commonwealth of Australia $v$ HREOC (Dopking No. 2) (1995) 63 FCR 74; 133 ALR 629.

49 In addition, the amendments provided that special measures to advance women were not discriminatory (SDA, s. 7D).
} 
These changes, which brought the focus of indirect discrimination onto practices that unreasonably disadvantage groups identified by sex, marital status or pregnancy, and especially reversing the onus of proof of reasonableness, were expected to make SDA litigation easier. Apart from a number of cases dealing with the right to return to work part-time after maternity leave (discussed below), there has, however, been little indirect discrimination litigation. Perhaps the other barriers already discussed outweighed the effect of these changes. Again, the reasons for this can only be the subject of speculation, as there is no published research or information that might provide an answer. ${ }^{50}$ The precedents regarding 'not reasonable' could still deter litigation despite the changed onus of proof or it could be that what has to be proved is too unclear or still too onerous. The test for disadvantage requires judges to develop criteria for identifying effects that 'disadvantage' women, ${ }^{51}$ which is a very open-textured test. In a recent interlocutory decision in a case claiming indirect discrimination under the $S D A$, the respondent mounted arguments about selection of pools for comparison in order to establish disadvantage, harking back to the approach in Banovic. ${ }^{52}$ The apparent strengthening of the law could be illusory, but in the absence of case law, what the law requires is not clear.

The decision of Commissioner Elizabeth Evatt in the 1996 Human Rights and Equal Opportunity Commission case Hickie $v$ Hunt and Hunt ${ }^{53}$ showed that indirect discrimination law could sometimes provide an avenue to deal with social practices that exclude women where the decision was made by a decision maker who understood the equality issues involved. In that case, the Human Rights and Equal Opportunity Commission held that failure to support a law firm partner in undertaking part-time work as agreed following her return from maternity leave amounted to indirect discrimination. This was based on accepting that a requirement to work full-time disadvantaged women on the basis of sex, because their gender-associated primary-caring responsibilities made it more difficult for them to comply. A series of cases followed in which this argument was either accepted or rejected in some cases where employers argued that they did not offer part-time employment to anyone in their workforce and had no part-time work available. ${ }^{54}$ As mentioned above, only two cases have been successful in this argument, and there have been no other attempts to argue indirect discrimination that have reached final judgment in SDA cases.

\footnotetext{
50 The cases and outcomes cited in Note 48 represent a serious deterrent to future litigation. See also Margaret Thornton, 'Sex Discrimination, Courts and Corporate Power' (2008) 36 Federal Law Review 31.

51 Ironically, this has been pointed out by the Australian Industrial Relations Commission, although never discussed by a court: Australian Municipal, Administrative, Clerical and Services Union v Moreland City Council PR972644 [2006] AIRC 318 at [7]. See also Wylie v McCann Worldgroup Pty Ltd \& Ors [2009] FMCA 959 ('Wylie') at [85]-[88] and [100]-[104].

52 Wylie at [86].

53 [1998] HREOCA 8.

54 Indirect discrimination cases succeeded in Escobar v Rainbow Printing Ltd (No. 2) (2002) 120 IR 84; [2002] FMCA 122, and Mayer $v$ ANSTO [2003] FMCA 209, but failed in Kelly v TPG Internet [2003] FMCA 584 and
} 
This avenue to work flexibility is not, however, available to men because it rests on the disproportionate impact of the requirement to work full-time on women as a group. Indirect discrimination law has proved insufficient to bring about the changes needed to help women (and men) make progress towards equality at work and in caring responsibilities. The current trend is to follow the UK model of introducing specific provisions providing employees with young or disabled children a right to request flexible work and requiring employers to provide a business-based answer. Such rights had been introduced in the industrial relations system in the Australian Industrial Relations Commission's Family Provision test case of $2005,{ }^{55}$ but were abolished by the WorkChoices scheme that existed from 2006 to 2008, and have now been reintroduced in the Fair Work Act 2009 (Cth). ${ }^{56}$

In parallel with those developments, a series of cases showed exactly how unpredictable the 'not reasonable' limit on indirect discrimination could be and how difficult it was for a complainant to establish that the employer's requirement was 'not reasonable'. The term has no defined degree and has been applied by judges almost as a matter of personal assessment. In several cases, respondents were able to challenge decisions of tribunals or lower courts that found discrimination merely by convincing an appeal court to apply a different test of 'reasonable' or to take a different view of what was reasonable on the facts as proved. ${ }^{57}$ This level of uncertainty must produce hesitation on the part of litigants to bring claims at all, and undermines the use of indirect discrimination.

In 2008, the Senate Legal and Constitutional Affairs Committee reported on The Effectiveness of the Commonwealth Sex Discrimination Act 1984 in Eliminating Discrimination and Promoting Gender Equality. ${ }^{58}$ The committee recommended a large number of changes that could be adopted quickly, together with a more detailed investigation into further reforms. No action has been taken, however, and the SDA still awaits amendment.

The most recent High Court sex discrimination decision illustrates how indirect discrimination law has proved not to be an effective method for challenging gendered social practices. In NSW $v$ Amery, ${ }^{59}$ a group of female long-term casual teachers complained of sex discrimination because their pay scale stopped at the equivalent of level eight of the 13-point pay scale available to permanent teachers. Women were disproportionately represented in the long-term casual category, because permanent teachers could be posted anywhere in the State.

\footnotetext{
Howe $v$ Qantas Airways Ltd (2004) 188 FLR 1; [2004] FMCA 242.

55 Family Provisions Case-PR082005 [2005] AIRC 692.

56 Fair Work Act 2009 (Cth), Part 2-2, Division 4: National Employment Standards.

57 See cases cited in Note 48.

58 See <http://www.aph.gov.au/Senate/committee/legcon_ctte/sex_discrim/index.htm>

59 New South Wales v Amery (2006) 230 CLR 174, [2006] HCA 14 (Amery). This case was brought under the Anti-Discrimination Act 1977 (NSW).
} 
To avoid such a posting for reasons of child care or their husband's job, many women who were permanent teachers reverted to casual status when they had children, and women were over-represented as long-term casuals and underrepresented as permanent teachers. Their indirect sex discrimination claim was upheld by the NSW Court of Appeal, but the High Court rejected it, saying that permanent and casual teacher categories could not be regarded as one job category to which a condition - of being a permanent teacher - was applied to access the higher pay scale. Instead, they were completely different job categories because of the importance of the requirement to be redeployable. ${ }^{60}$ This decision is further evidence of the legal system's refusal to take account of the structure of women teachers' lives, insisting that they have to conform to the male career model in order to access men's pay.

The Amery decision confirms that neither direct nor indirect discrimination law is sufficient to bring about the changes to the deeply embedded social and employment practices necessary for greater equality at work. The SDA has not limited workforce practices, conditions and expectations that are based on an assumption that the worker is free of care responsibilities. This is not equality for women and it is not surprising that the data on women's position in Australia today indicate that equality has not been achieved, and there is still a long way to go.

\section{Women in Australia Today}

Data on the position of women indicate that women in Australia are not progressing towards equality. Statistics collated by the Sex Discrimination Commissioner show, compared with other developed countries, in Australia, progress towards equality for women has been disappointing. ${ }^{61}$ Women represent more than 50 per cent of the Australian population, but held only 29 per cent of elected positions in the 2007 Australian Parliament. Among the Australian Stock Exchange's top-200 companies, women chair only 2 per cent of boards (four boards), hold only 8.3 per cent of board directorships, only four chief executive officer positions and only 10.7 per cent of executive management positions. Although Australia is in a group of countries ranked number one for women's educational attainment, it ranks 41 for women's participation in the workforce, 17 overall in the Global Gender Gap Index and 28 in the world for women's representation in Parliament. Women are 45.1 per cent of the Australian

60 In addition, the distinction was found in the Education Act 1990 (NSW), which authorised, but did not require, different pay scales: Amery at [73]-[83], per Gleeson CJ. Cf. Kirby J (dissenting) at [154]-[155].

61 Australian Human Rights Commission, 'Sex Discrimination Commissioner: 25th Anniversary of the Sex Discrimination Act (1984)', Gender Equality Statistics, Australian Human Rights Commission, Sydney, 1984, $<$ http://www.hreoc.gov.au/sex_discrimination/sda_25/index.html> 
workforce, and 58.9 per cent of women participate in the workforce compared with 72.1 per cent of men, but many women work part-time and casual jobs to fit in family responsibilities. Women earn 84.3 cents in the male dollar (for full-time adult ordinary-time earnings), but only 66 per cent of what men earn overall, because of their part-time status and the slight widening of the gender pay gap during the WorkChoices period from 2005 to 2008.

The Australian Human Rights Commission's recent report Accumulating Poverty? Women's Experiences of Inequality over the Lifecycle ${ }^{62}$ identifies the consequences of women's systematic exclusion from economic participation by undervaluing the work that they do, and the workforce's refusal to adjust to enable women to maintain both caring work and decently paid work, and men to share responsibility for both. ${ }^{63}$ While factors such as neo-liberalism have contributed to the lack of progress (and even regression) for women, some problems in the Act are also significant. ${ }^{64}$ Its definitions of discrimination were weaker at the outset than those of comparable overseas laws and its enforcement depended solely on litigation by the victims of discrimination - no small matter for someone who had lost their job or endured sexual harassment at work, especially given the very limited legal aid in this area. When cases have been litigated, narrow and technical interpretations have often been adopted, especially by the higher courts, as in Amery, which have further weakened the law as a weapon against discrimination. In successful cases, damages have been quite low. There is limited incentive to enforce the law, and hence limited pressure through the law for change in social and workforce practices to avoid discrimination. Thus, the $S D A$ appears to have had limited impact on the structural features that construct women's disadvantage.

\section{Paradoxes of Change and Lack of Change}

The result is that after 25 years of the $S D A$, workplaces still operate on the assumption that the 'normal' employee is a full-time worker with no domestic caring responsibilities or that they have someone to fulfil those responsibilities for them. Sex discrimination law has not been effective to challenge this model, which fits men's but not women's lives. The male norm at work is

\footnotetext{
62 Australian Human Rights Commission, Accumulating Poverty: Women's Experiences of Inequality over the Lifecycle, Australian Human Rights Commission, Sydney, 2009.

63 See also YWCA Australia and Women's Legal Services Australia, NGO Report on the Implementation of the Convention on the Elimination of All Forms of Discrimination Against Women (CEDAW) in Australia, [Shadow Report to Australia's Periodic Report to the CEDAW Committee], July 2009; and Elizabeth Broderick, Life Lines: Sex Discrimination over the Lifecycle, The Australian National University, Canberra, <http://law.anu. edu.au/coast/events/Sex_Discrim/Broderick_paper.pdf $>$

64 Sandra Berns, Women Going Backwards: Law and Change in a Family Unfriendly Society, Ashgate Aldershot, Hants, UK, 2002; and Thornton, 'Auditing the Sex Discrimination Act'.
} 
further maintained through women's exposure to sexual harassment, gender pay inequity and working conditions that do not make allowances for caring responsibilities that are assumed to be women's obligations. This virtually ensures that many women will 'choose' to take the available casual and parttime, often poorly paid jobs in retail, clerical and community services, which enable them to both carry out the care responsibilities that are regarded as theirs and remain in the workforce. Women can also be forced into these areas by the process of work intensification and the move to long hours or by the casualisation and deterioration of pay and working conditions for the low paid that have occurred in the past decade.

Recent moves to allow employees to request flexible work hours to manage their care responsibilities ${ }^{65}$ have come through the industrial law system rather than sex discrimination law. There have, however, been no initiatives to encourage men to share care responsibilities or to solve the underlying problems of gender pay inequity, sexual harassment and the male norm of the ideal worker. Paid parental leave will arrive (eventually) in 2011, but unless the underlying problems are addressed, paid parental leave without encouragement for men to take their share of responsibility for child care will simply reinforce women's responsibility for infant care and subsequent child care. In easing the workfamily conflict for women, the equality laws have failed to disrupt women's assumed primary responsibility for child care.

Employment practices that disadvantage women because they do not meet stereotypical expectations, or because they have care responsibilities that might restrict their mobility or ability to work long hours, have not changed. It is hard to see how women can be equal in the workforce unless such practices are challenged. ${ }^{66}$ Our social and economic arrangements ensure that women are poorer throughout their lives than comparable men and face poverty in much higher proportions in retirement. ${ }^{67}$ Despite apparent advances for women in

65 This is one of the rights in the National Employment Standards for all employees under the Fair Work Act 2009 (Cth) (Part 2-2, Division 4 [ss 65-6]). The 'right to request' is only a procedural, not a substantive, rightto request flexible conditions of work and to receive an answer that addresses the substance of the employer's workforce needs, not simply a blanket refusal. There is no mechanism for directly enforcing any such right, although a refusal that was discriminatory could be the subject of a discrimination complaint. A similar right in the United Kingdom has been successful, but defines the permissible grounds for refusing more clearly (see Employment Rights Act 1996 [UK], s. 80G), and is supported by a right to complain to an employment tribunal where the employer fails to comply with the requirements of the Act (s. $80 \mathrm{H})$.

66 Commentators no longer believe that the 'pipeline effect' (that women have not yet come through the system in sufficient numbers to move into senior positions) is the reason for these disparities, since they have persisted despite women's presence in substantial numbers in the workforce and professions over several decades.

67 Australian Human Rights Commission, Accumulating Poverty. The statistics referred to in Note 61 show that in 2007, 2.8 million women and 1.6 million men aged fifteen years and over reported not being covered by superannuation; half of all women aged between forty-five and fifty-nine have $\$ 8000$ or less in superannuation; and current superannuation payouts for women are one-third of men's $-\$ 37000$ compared 
the workforce, these data confirm that many women are only a relationship breakdown away from poverty - a situation that has changed very little in past centuries.

The SDA has not even begun to engage with the paradox that making child care easier for employed women to access simply reinforces their responsibility for it, thereby cementing their disadvantage. It is only by disrupting the gendered link to care work that improvements in conditions will be more widespread and could allow both women and men the ability to function effectively in both work and care. This is a step towards the most substantial aim - of disrupting gender-based norms as the ideal on which the system of employment rests - so that the male pattern is the norm and the female pattern the exception that falls short.

Language frames our thinking about what is possible in future. Women have, however, been largely removed from government language in Australia. Under the Howard Liberal Government (1996-2007), virtually all references in government policy and publications to women disappeared. References were made only to families and 'women's' interests were assumed to be those of their families. With the election of the Rudd Labor Government, this became a reference to 'working families'. Progress towards government recognition of the interests of women themselves (as well as the interests of men and children) is very slow, and ground that was gained during the 1980s has substantially been lost. Instead, the economic discourse of efficiency prevails.

Equality is also at risk of being overtaken and disappearing under the new discourse of human rights. Equal opportunity has been removed from the title of the Australian Human Rights Commission (previously the Human Rights and Equal Opportunity Commission) and its governing act, and the Gardner Review of Victoria's Equal Opportunity Act recommended that the Victorian Equal Opportunity and Human Rights Commission be renamed Human Rights Victoria. The spotlight now is on human rights, which is supposed to include equality. Equality as a collective right does not, however, necessarily sit easily with the individualist ethos of human rights and its fortunes appear to be slipping as those of human rights expand. Debate about equality in Australiawhether for women, racial or ethnic groups, Indigenous people or people with disabilities - is very limited.

with $\$ 110000$. At the same time, government policies direct support through superannuation subsidies to those with the highest salaries and greatest workforce connection, rather than individuals whose need is greatest (for example, through social security pensions). 


\section{Assessing the Act's Achievements: The Need for Change at the Systemic Level}

In comparison with the days before the $S D A$, there have been major advances in women's position. In more recent times and compared with other developed countries, however, its achievements look more problematic. Arguably, sex discrimination law based on private enforcement has failed. While it is necessary for individuals to have an avenue to seek compensation for harms they suffer, to leave this as the sole enforcement method suggests a lack of commitment to ensuring that discrimination stops. Sex discrimination needs to be recognised as a broad social problem, not just a problem for the few individuals who recognise it and are prepared to fight for their rights. It must be tackled at a systemic level in order to change practices on a society-wide basis. The responsibility for enforcement has to be undertaken publicly and be directed towards changing systemic practices rather than solely redressing individual cases. Sex discrimination law needs better tools to tackle systemic practices that continue to disadvantage women.

Advances for women will not be possible unless change is also made possible for men in relation to the balance between work and care in their lives. Australian men are presently deprived of choice about their role in the family, with very limited access to parental leave and with strong social and employer inhibition on making less conventional choices.

Ironically, change could come through the industrial relations system rather than anti-discrimination law. The Fair Work Act 2009 (Cth) includes provisions prohibiting discrimination at work that have the potential to virtually replace anti-discrimination laws in relation to employment discrimination. Of particular importance is that the Fair Work Act system includes an active and well-resourced public agency charged with enforcing the law (the Fair Work Ombudsman) and provides that litigation in the Federal Courts to enforce the 'adverse action' provisions does not attract the usual costs rules. The industrial relations system, based on collectivist ideas of employee organisations to protect and maintain rights, counterbalances the power of employers over employees, and of judges whose professional orientation is maintenance of the current system. ${ }^{68}$ It could prove more able to address the concerns of women about the gendered nature of workforce assumptions and practices than individualised sex discrimination laws. It could, however, take some years to determine whether the potential of the new provisions will be realised.

68 Thornton, 'Sex Discrimination, Courts and Corporate Power' 33. 
In the years since the $S D A$ was adopted, we have learned a bit more about the phenomena of discrimination and prejudice. Valian has sought to explain why women's disadvantage is so difficult to alter based on the social-psychological theory of gender schemas in the cognitive processes of the individual. ${ }^{69}$

According to this theory, schemas are sets of expectations and assumptions that we all use every day to save ourselves from having to work things out from the beginning. They are cognitive shortcuts and include but are not limited to stereotypes and they exist below our conscious awareness. Among the most powerful are the gender schemas, which are sets of expectations that were formed and learned from our environments from birth and that are shaped by the world in which we live and the way things are done. Valian argues that gender schemas affect all of us, even those who consciously seek to end women's disadvantage. The effect of gender schemas is to create unconscious expectations that can lead to subtle and small differences in expectations and treatment of men and women that are repeated many times and that accumulate to result in large differences in overall outcomes. Valian argues that women's disadvantage is not necessarily the result of any large or egregious barriers or acts of discrimination, but instead the result of pervasive and repeated small disadvantages. This is not to deny that there are egregious violations of women's rights in Australia and elsewhere - for example, in relation to Indigenous women, family violence, and so on. Instead, this is a theory about one of the less noticeable causes of women's general disadvantage and why it is so difficult to challenge.

If gender schemas have this effect then it is difficult to see how individual legal remedies could be effective. The role of law is usually to deal with harms that are sufficiently serious to justify the cost and formality of legal intervention. Where differences in treatment are small but pervasive, they can be seen individually as trivial and not justifying legal intervention. This view makes a change of emphasis to systemic processes absolutely necessary, with a focus on changing practices and patterns that disadvantage, or on ensuring outcomes become more similar as an indication that disadvantage is not continuing, rather than identifying specific harms of sufficient degree. Focusing on sex discrimination law, which appears to be relatively ineffective in bringing about needed changes, could be an indication of the 'mesmerising' effect of general equality claims. ${ }^{70}$ Instead of relying on a general claim to equality that is so open textured and subvertible, reformers might achieve more by focusing on the intellectual work and detailed analysis needed to push for identified changes to specific social practices.

69 Virginia Valian, Why So Slow? The Advancement of Women, MIT Press, Cambridge, Mass, 1998.

70 Margaret Thornton, 'Rapunzel and the Lure of Equal Citizenship' (2004) 8 Law/Text/Culture 231, 239. 
Another argument for systemic and proactive rather than retrospective focus is that accusing a person of discrimination could be more likely to limit than to produce change, even at the individual level. It is likely to make the person feel defensive and refuse to change, because change could be seen as an admission that their practices were discriminatory. This phenomenon is often seen in response to litigation. Moving to proactive duties takes the emphasis in enforcement away from individual cases and past actions, and puts it on the systems that need to change. ${ }^{71}$

Comparable countries have placed much more emphasis on enforcement by public authorities, such as equality agencies, and on developing proactive requirements. For example, the United Kingdom has an equality duty that requires public sector bodies to consider women's (and other) equality issues in all policy development and service provision. ${ }^{72}$ The UK Equality Bill 2010 has provisions for requiring employers of more than 250 staff to report on pay equity in their workforces, to provide the greatest chance of change. ${ }^{73}$ The United States requires companies seeking government contracts to comply with affirmative action requirements (relating to minorities as well as gender) and ensure their subcontractors do so as well. Some Australian governments have used this approach in very limited areas - such as equal opportunity in briefing barristers - yet there is scope for much broader application. ${ }^{74}$ These approaches are still in their early stages. Effective regulation requires a substantial investment in enforcement and monitoring, and there is some risk that they could become merely bureaucratic exercises or burdensome and difficult to monitor and enforce broadly.

There is another possible alternative. Norway has imposed quotas on women's board representation since the mid-2000s with success, and France is currently considering doing so. France has a quota for women's representation as political candidates. Closer to home, the ALP has had an affirmative action quota for women in winnable seats that has been highly effective in increasing women's representation in the current government. Even the Australian Stock Exchange has recently adopted a policy that requires changes to be demonstrated in women's participation on boards to avert the imposition of a quota. ${ }^{75}$ Quotas

\footnotetext{
71 Belinda Smith, 'A Regulatory Analysis of the Sex Discrimination Act 1984 (Cth): Can It Effect Equality or Only Redress Harm?' in Joanne Conaghan and Kerry Rittich (eds), Labour Law, Work, and Family: Critical and Comparative Perspectives, Oxford University Press, New York, 2005, p. 105.

72 Simon Rice, this volume; and Sandra Fredman, Human Rights Transformed: Positive Rights and Positive Duties, Oxford University Press, UK, 2008.

73 Equality Act 2010 (UK), s. 78. Enforcement provisions for this requirement that were in the Equality Bill 2009 (UK) (cl 75), as introduced in the House of Commons, were, however, deleted in the House of Lords.

74 See, for example: Christopher McCrudden, Buying Social Justice: Equality, Government Procurement, and Legal Change, Oxford University Press, UK, 2007.

75 Australian Securities Exchange, Recommendations on Diversity, December 2009, Corporate Governance Council, Australian Securities Exchange, Sydney, <http://www.asx.com.au/about/pdf/mr_071209_asx_cgc_ communique.pdf $>$
} 
seem consistent with modern management approaches that concern themselves with outputs and results, rather than inputs or processes. Despite media hysteria about quotas, after 25 years, this could be the stronger alternative necessary to keep faith with the generations of women who have been promised equality but found the promise to be empty.

\section{Conclusion}

Although the SDA has been vital to progress, it has not been enough, and thorough legislative reform will be needed for greater progress. At 25, it has been outflanked by social change and economic ideology, ${ }^{76}$ while media and much public discourse asserts that women are now equal. Sex discrimination law based on private enforcement has not been up to task. There is an urgent need for change, towards dealing with systemic discrimination and ensuring that public enforcement action is taken. While individuals need an avenue to seek compensation for harms they suffer, relying solely on private enforcement reflects a weak commitment to stopping discrimination. Sex discrimination needs to be recognised as a broad social and structural problem, and tackled at a systemic level. The burden of enforcement has to be undertaken publicly and be directed towards changing systemic practices rather than solely to redressing individual cases.

Although the need for reform has been recognised in recent reviews of antidiscrimination law, ${ }^{77}$ there is no sign yet of any legislative change. Strengthening the Act's substantive provisions without addressing enforcement is unlikely to produce real social change on the wide basis needed. Systemic enforcement that does not rely on the individual affected to take action offers the best way forward for broad-based change. To maximise the chances of social change, a focus on positive duties and proactive measures that could help to counteract gender schemas and stereotyping appears most promising. After the SDA's silver anniversary, more effective action is needed to keep faith with the generation of women who have been promised, but not yet allowed, equality.

\footnotetext{
76 Hunter, 'The Mirage of Justice'.

77 See, for example: Senate Legal and Constitutional Committee, Report on the Effectiveness of the Commonwealth Sex Discrimination Act 1984 in Eliminating Discrimination and Promoting Gender Equality, Parliament of Australia, Canberra, 2008; Department of Justice, An Equality Act for a Fairer Victoria: Report of the Equal Opportunity Review, Government of Victoria, Melbourne, [Gardner Review], 2008.
} 


\section{Bibliography}

\section{Books and articles}

Allen, Dominique, 'Reducing the Burden of Proving Discrimination in Australia' (2009) 31(4) Sydney Law Review 579.

Berns, Sandra, Women Going Backwards: Law and Change in a Family Unfriendly Society, Ashgate Aldershot, Hants, UK, 2002.

Broderick, Elizabeth, Life Lines: Sex Discrimination over the Lifecycle, The Australian National University, Canberra, < http://law.anu.edu.au/coast/ events/Sex_Discrim/Broderick_paper.pdf>

Conaghan, Joanne and Rittich, Kerry (eds), Labour Law, Work, and Family: Critical and Comparative Perspectives, Oxford University Press, New York, 2005.

Department of Justice 2008, An Equality Act for a Fairer Victoria: Equal Opportunity Review Final Report, Department of Justice, Government of Victoria, Melbourne, [Gardner Report], <http://www.justice.vic.gov.au/wps/ $\mathrm{wcm} /$ connect/DOJ+Internet/Home/Your+Rights/Equal+Opportunity/>

Fredman, Sandra, Human Rights Transformed: Positive Rights and Positive Duties, Oxford University Press, UK, 2008.

Gaze, Beth, 'Context and Interpretation in Anti-Discrimination Law' (2002) 26 Melbourne University Law Review 325.

Gaze, Beth and Hunter, Rosemary, Access to Justice for Discrimination Complainants: Courts and Legal Representation' (2009) 32 University of New South Wales Law Journal 699.

Gaze, Beth and Hunter, Rosemary, Enforcing Rights in Australia: An Evaluation of the New Regime, Federation Press, Sydney, (forthcoming).

Graycar, Regina and Morgan, Jenny, The Hidden Gender of Law, Second edition, Federation Press, Sydney, 2002.

Graycar, Regina and Morgan, Jenny, 'Examining Understandings of Equality: One Step Forward, Two Steps Back?' (2004) 20 Australian Feminist Law Journal 23.

Graycar, Regina and Morgan, Jenny, 'Thinking about Equality' (2004) 27 University of New South Wales Law Journal 833.

Hunter, Rosemary, Indirect Discrimination in the Workplace, Federation Press, Annandale, NSW, 1992. 
Hunter, Rosemary, 'The Mirage of Justice: Women and the Shrinking State' (2002) 16 Australian Feminist Law Journal 53.

Hunyor, Jonathon, 'Skin-Deep: Proof and Inferences of Racial Discrimination in Employment' (2003) 25 Sydney Law Review 535.

Innes, Jane, 'Claiming Equal Pay for Work of Equal Value: The ACTU's Comparable Worth Test Case' (1986) 4 Law Society Journal 52.

Innes, Jane, 'Equal pay and the Sex Discrimination Act 1984' (1986) 11 Legal Service Bulletin 254.

McCrudden, Christopher, Buying Social Justice: Equality, Government Procurement, and Legal Change, Oxford University Press, UK, 2007.

MacKinnon, Catharine, Feminism Unmodified: Discourses on Life and Law, Harvard University Press, Cambridge, Mass., 1987.

Primus, R., 'Equal Protection and Disparate Impact: Round Three' (2003) 117 Harvard Law Review 493.

Rees, Neil, Lindsay, Katherine and Rice, Simon, Australian Anti-Discrimination Law: Text, Cases and Materials, Federation Press, Sydney, 2008.

Smith, Belinda, 'A Regulatory Analysis of the Sex Discrimination Act 1984 (Cth): Can It Effect Equality or Only Redress Harm?' in Joanne Conaghan and Kerry Rittich (eds), Labour Law, Work, and Family: Critical and Comparative Perspectives, Oxford University Press, New York, 2005.

Thornton, Margaret, 'The Indirection of Sex Discrimination' (1993) 12 University of Tasmania Law Review 88.

Thornton, Margaret, 'Rapunzel and the Lure of Equal Citizenship' (2004) 8 Law/ Text/Culture 231.

Thornton, Margaret, 'Auditing the Sex Discrimination Act' in Marius Smith (ed.), Human Rights 2004: The Year in Review, Castan Centre for Human Rights Law, Monash University, Melbourne, 2005.

Thornton, Margaret, 'Sex Discrimination, Courts and Corporate Power' (2008) 36 Federal Law Review 31.

Valian, Virginia, Why So Slow? The Advancement of Women, MIT Press, Cambridge, Mass., 1998.

Walker, Kristen, 'The Bishops, the Doctor, his Patient and the Attorney-General: the Conclusion of the McBain Litigation' (2002) 30 Federal Law Review 507. 
Sex Discrimination in Uncertain Times

\section{Legislation}

Anti-Discrimination Act 1977 (NSW)

Disability Discrimination Act 1992 (Cth)

Education Act 1990 (NSW)

Employment Rights Act 1996 (UK)

Equal Opportunity Act 1977 (Vic.)

Equal Opportunity Act 1984 (SA)

Equal Opportunity Act 1984 (WA)

Equal Opportunity Act 1995 (Vic.)

Fair Work Act 2009 (Cth)

Prohibition of Discrimination Act 1966 (SA)

Racial Discrimination Act 1975 (Cth)

Racial Discrimination Act 1976 (SA)

Sex Discrimination Act 1984 (Cth)

\section{Cases}

Ansett Transport Industries (Operations) Pty Ltd $v$ Wardley (1980) 142 CLR 237; [1980] HCA 8

Australian Iron \& Steel Pty Ltd v Banovic (1989) 168 CLR 165; 1989 HCA 56

Australian Municipal, Administrative, Clerical and Services Union v Moreland City Council PR972644 [2006] AIRC 318

Brandy v Human Rights \& Equal Opportunity Commission, (1995) 183 CLR 245; [1995] HCA 10

Commonwealth Bank of Australia v Human Rights and Equal Opportunity Commission (1997) 150 ALR 1; [1997] FCA 1311

Commonwealth of Australia $v$ Evans (2004) 81 ALD 402; [2004] FCA 654

Commonwealth $v$ Human Rights and Equal Opportunity Commission (Dopking No. 2) (1995) 63 FCR 74 
Dao v Australian Postal Commission (1987) 162 CLR 317; [1987] HCA 13

Elliott v Nanda \& Commonwealth (2001) 111 FCR 240; [2001] FCA 418

Escobar v Rainbow Printing Ltd (No. 2) (2002) 120 IR 84; [2002] FCMA 12

Family Provisions Case PR082005 [2005] AIRC 692

Fenton v Hair \& Beauty Gallery Pty Ltd \& Anor [2006] FMCA 3

Gilroy v Angelov [2000] FCA 1775

Griggs v Duke Power Co. 401 US 424 (1971); (1971) 28 L Ed 2d 158

Grulke v K C Canvas Pty Ltd [2000] FCA 1415

Hickie $v$ Hunt and Hunt [1998] HREOCA 8

Howe v Qantas Airways Ltd (2004) 188 FLR 1; [2004] FCMA 242

Iliff v Sterling Commerce (Australia) Pty Ltd [2007] FMCA 1960

Kelly v TPG Internet [2003] FMCA 584

Kirkland $v$ Wattle [2002] FCA 145

Lee $v$ Smith \& Ors [2007] FMCA 59

Mayer $v$ ANSTO [2003] FMCA 209

New South Wales v Amery (2006) 230 CLR 174; [2006] HCA 14

Poniatowska $v$ Hickinbotham [2009] FCA 680

Re McBain; Ex parte Australian Catholic Bishops Conference (2002) 209 CLR 372;

[2002] HCA 16

Secretary, DFAT v Styles (1989) 23 FCR 251

Thomson v Orica Australia Pty Ltd (2002) 116 IR 186; [2002] FCA 939

Wattle $v$ Kirkland \& Anor (No. 2) [2002] FMCA 135

Wylie v McCann Worldgroup Pty Ltd \& Ors [2009] FMCA 959

\section{Reports and miscellaneous primary sources}

Australian Human Rights Commission, Accumulating Poverty: Women's Experiences of Inequality over the Lifecycle, Australian Human Rights Commission, Sydney, 2009. 
Australian Human Rights Commission, 'Sex Discrimination Commissioner: 25th Anniversary of the Sex Discrimination Act (1984)', Gender Equality Statistics, Australian Human Rights Commission, Sydney, 2009, <http:// www.hreoc.gov.au/sex_discrimination/sda_25/index.html>

Australian Law Reform Commission, Equality Before the Law: Justice for Women, Report 69, Australian Law Reform Commission, Sydney, 1994.

Australian Securities Exchange, Recommendations on Diversity, Corporate Governance Council, Australian Securities Exchange, Sydney, 2009, $<$ http://www.asx.com.au/about/pdf/mr_071209_asx_cgc_communique. $\operatorname{pdf}>$

European Union, Directive on the Burden of Proof of Discrimination

Human Rights and Equal Opportunities Commission, The Equal Pay Handbook, Human Rights and Equal Opportunities Commission, Sydney, 1998.

Human Rights and Equal Opportunities Commission, Pregnant and Productive: It's a Right not a Privilege to Work while Pregnant, Human Rights and Equal Opportunities Commission, Sydney, 1999.

Human Rights and Equal Opportunities Commission, A Bad Business: Review of Sexual Harassment in Employment Complaints, Human Rights and Equal Opportunities Commission, Sydney, 2002.

Human Rights and Equal Opportunities Commission, A Time to Value: Proposal for a National Scheme of Paid Maternity Leave, Human Rights and Equal Opportunities Commission, Sydney, 2002.

Human Rights and Equal Opportunities Commission, Striking the Balance: Women, Men, Work and Family, Human Rights and Equal Opportunities Commission, Sydney, 2005. 